\title{
THE EFFECT OF BUSINESS UNIT, PRODUCTION, PRIVATE INVESTMENT, AND MINIMUM WAGE ON THE LABOR ABSORPTION IN THE LARGE AND MEDIUM INDUSTRY 6 PROVINCES IN JAVA ISLAND
}

\author{
Dini Amalia \\ Economic and Business Faculty of Diponegoro University \\ Email: diniamalialia@gmail.com \\ Nenik Woyanti \\ Economic and Business Faculty of Diponegoro University \\ Email:neniwoyanti346@gmail.com
}

Received: Juni 2020; Accepted: July 2020; Available online: July 2020

\begin{abstract}
Industry sectors in Java Island viewed as high productivity sector, therefore high value-added will be generated from the advantage of this industry that will eventually fastened the creation of economical prosperity. Large and medium Industry have potency to become the most contributed sector on labor absorption of manpower. The purpose of this study was to analyze mapping of Labor absorption in the large and medium industry using Klassen typology analysis and determine the effect of variable Large and Medium Industry, Production Value, Private Investment, and Regional Minimum Wage on employment large and medium industry 6 provinces in Java Island for years 2008-2017. This research is using Klassen Typology and Panel data analysis with Fixed Effect Model (FEM). The result of Klassen typology Analysis indicate, there are 2 provinces in Quadrant I, 1 province in Quadrant II, 1 province in Quadrant III, and 2 provinces in Quadrant IV. The Panel data result shows that Large and Medium Industrial unit and Private Investment have positive and significant impact, while Production Value and Regional Minimum Wage have positive and non significant impact on Labor absorption in the Large and Medium Industry 6 provinces in Java Island for years 2008-2017.
\end{abstract}

Keywords: Labor absorption of manpower Large and Medium Industry, Business unit, Production Value, Private Investment, Regional Minimum Wage.

\begin{abstract}
Abstrak
Sektor industri di Pulau Jawa dipandang sebagai sektor yang memiliki tingkat produktifitas yang tinggi, sehingga dengan keunggulan sektor industri akan didapat nilai tambah yang tinggi yang pada akhirnya tujuan menciptakan kesejahteraan masyarakat secara ekonomi lebih cepat terwujud. Industri besar dan sedang memiliki potensi untuk menjadi sektor yang paling berkontribusi dalam penyerapan tenaga kerja. Penelitian ini bertujuan untuk menganalisis pemetaan penyerapan tenaga kerja industri besar dan sedang dengan analisis Tipologi Klassen serta bagaimana pengaruh jumlah unit usaha, nilai produksi, investasi swasta, dan upah minimum terhadap penyerapan tenaga kerja industri besar dan sedang 6 provinsi di Pulau Jawa tahun 2008-2017. Metode yang digunakan dalam penelitian ini adalah analisis tipologi klassen dan data panel dengan fixed effect model (FEM). Hasil analisis tipologi klassen menunjukkan bahwa terdapat 2 provinsi yang berada di kuadran I, 1 provinsi di kuadran II, 1 provinsi di kuadaran III, dan 2 provinsi di kuadran IV. Hasil analisis data panel menunjukkan bahwa variabel jumlah unit usaha dan investasi swasta berpengaruh positif dan signifikan terhadap penyerapan tenaga kerja industri besar dan sedang, sedangkan variabel nilai produksi dan upah minimum berpengaruh positif dan
\end{abstract}


tidak signifikan terhadap penyerapan tenaga kerja industri besar dan sedang 6 provinsi di Pulau Jawa tahun 2008-2017.

Kata kunci: Penyerapan Tenaga Kerja Industri Besar dan Sedang, Unit Usaha, Nilai Produksi, Investasi Swasta, Upah Minimum.

How to Cite: Amalia, D., \& Woyanti, N. (2020). The Effect of Business Unit, Production, Private Investment, and Minimum Wage on the Labor Absorption in the Large and Medium Industry 6 Provinces in Java Island. Media Ekonomi dan Manajemen, 35(2), 206-217. doi: http://dx.doi.org/10.24856/mem.v35i2.1550.

\section{INTRODUCTION}

Economic development aim to improve the welfare of society and the income per capita of a country. One supporting factor in economic growth can be seen from the absorption of labor that aims to reduce the number of unemployed and equitable distribution of income.

Indonesia is the largest archipelago country in the world, consisting of 5 large islands and 4 islands. One of the islands in Indonesia has the largest population, and the most significant area is Java. The average contribution of the people of Java Island in 2013-2017 is $56.77 \%$ of Indonesia's total population. The Increasing number of population can increase the amount of the labor force so that the increasing number of workers must be absorbed.

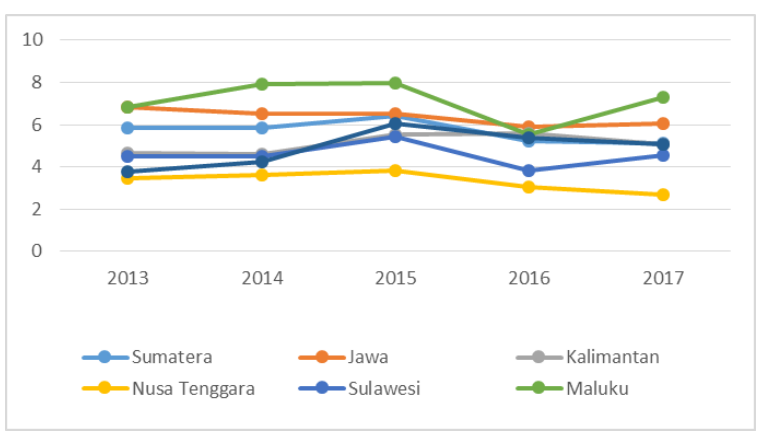

Figure 1. Contribution of Average Open Unemployment Rate By Island/ Archipelago in Indonesia 20132017 (Percent)

Source: (Badan Pusat Statistik), 20132017, proceed

The number of labor force that is not proportional to the availability of employment will result in unemployment, this is a problem for developing countries like
Indonesia. The open unemployment rate in Java in 2016 was the largest in Indonesia, amounting to $5.9 \%$. This indicates that the unemployment problem is one of the main problems that must be resolved. The level of unemployment in Java which tends to increase, illustrates the availability of employment that has not been optimal.

To overcome the large unemployment rate, each region requires leading sectors to absorb labor. One of them is the industrial sector; the industry is considered a pioneer in developing countries' economic development. According to data of Badan Pusat Statistik Indonesia, the contribution of the sector industry every year is the largest contributor to GDP in Indonesia.

Java Island is the island with the most significant number of manufacturing industry growth in Indonesia. It is influenced by the infrastructure that is very supportive concerning the growth of the processing industry, both small, medium, and large.

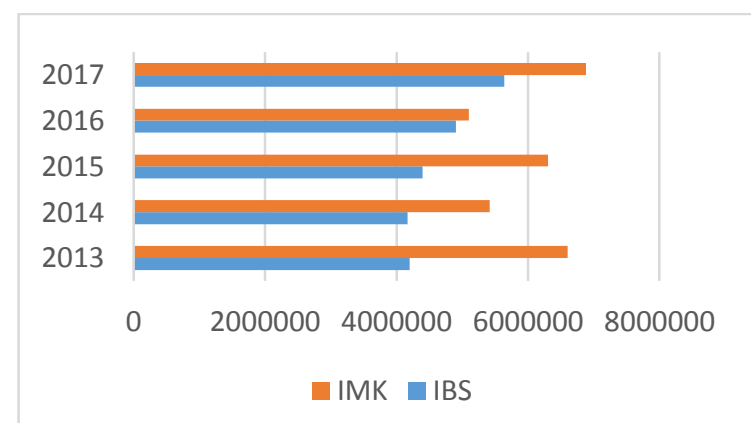

Figure 2. The number of IBS and IMK workers in 6 Provinces of Java in 2013-2017

Source: (Badan Pusat Statistik), 20132017, proceed 
The number of Large and Medium Industries (IBS) workers in 6 Provinces of Java in 2013-2017 is lower than the number of workers of Micro and Small Industries (IMK). It means we have to increase absorption of large and medium industrial workers.

The number of business units is closely related to employment in the industrial sector. Where there are a number of business units, it will directly increase the number of workers needed in an industry (Karib, 2012).

If the demand for the company's production increases, producers tend to increase their production capacity (Sumarsono, 2009) Increased production capacity can result in an increase in the workforce needed by a company, this causes the value of production to have a positive effect on employment.

According to Sukirno (2012) stated that to develop the industrial sector adequate investment is needed so that the development of the industrial sector can run as intended. Investment is one component of aggregate expenditure, so an increase in investment will increase aggregate demand and national income. Such an increase will always be followed by an increase in output. This has a positive impact on employment, because with the addition of output it will provide additional employment opportunities for the number of workers who are needed to produce 1 unit of output through public policy so that it can help reduce the number of unemployed.

An increase in the wage level will increase the company's production costs, further increasing the price per unit of goods produced. Usually consumers will give a quick response if there is an increase in the price of goods, namely reducing consumption or even not wanting to buy the item in question. As a result, many unsold goods are produced, and producers are forced to reduce their production quantities. The decline in production targets results in a reduction in the workforce needed (Sumarsono, 2009)

Based on the explanation above, the role of the large and medium industrial sector is considered very influential in employment. Therefore, research on the topic of employment is entitled "Impact of Business Units, Production, Private Investment, and Minimum Wages Against Large and Medium Labor Absorption of Industrial Sectors in the Province of Java."

The aim of this research is to mapping of large and medium absorption industrial workers in 6 Provinces of Java during 2008-2017 with Klassen Typology analysis; Determine the effect of the number of business units, production value, private investment, and partial minimum wages on the absorption of large and medium industrial workers in 6 Provinces of Java Island; Factors influence the absorption of large and medium industrial workers in 6 Provinces of Java; and Determine the influence of the number of business units, the value of production, private investment, and the minimum wage on the absorption of large and medium industrial workers in 6 Provinces of Java.

\section{LITERATURE REVIEW}

\section{Labor Demand}

According to Sumarsono (2009), labor demand is related to the amount of energy needed by specific companies or agencies. The change of wages usually influences the demand for this workforce and other factors affecting the results demand.

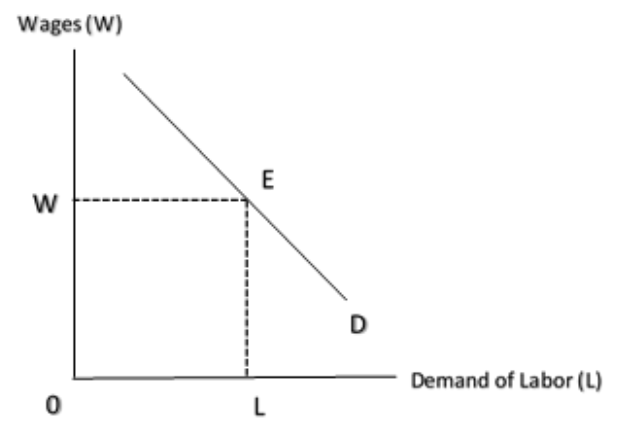

Figure 3. Demand of Labor Curve Source: Mankiw (2011) 
In picture explained relationship of wages and the demand for labor, the higher the rate of wages requested, the company will reduce the need for the amount of labor, while the decline in wages will likely increase the demand for energy.

If wages rise (assuming the price of goods other capital has not changed), then there are entrepreneurs who prefer to use capital-intensive technology for the production process and replaces the need for labor with the goods -Items capital crate engines and others. Decreasing the amount of labor needed because of the replacement or additional use of machines is called the substitution effect of labor or substitution effect (Sumarsono, 2009).

If the price of capital goods goes down, the production costs will go down, and of course, it will also cause the selling price per unit of goods to fall. In this situation, producers tend to increase the production of their goods due to greater demand. Besides, the demand for labor can increase due to the increase in company activities. This situation causes a shift in the labor demand curve towards the right, this shift is due to the influence of the scale of production or scale effect (Sumarsono, 2009).

\section{Labor Supply}

The concept of labor supply underlies the relationship between the amount of wages and the amount of labor provided by the owner of this workforce, so that the labor supply curve can be interpreted as a curve describing the amount of labor provided by the owner of labor at the income level for a certain period. When there is an increase in wages that will be taken on the workforce, then the amount provided will also increase. Higher, if the high wages provided go down, the amount of labor provided will also decrease. In general, slopes offer a positive workforce (Feriyanto, 2014)
Individuals with higher economic status (higher wages) will tend to increase consumption and enjoy more free time, thereby reducing work hours (income effect). On the other hand, an increase in the wage rate also means the price of time becomes more expensive. Higher time values encourage families to substitute their free time to work more to increase consumption of goods (Simanjuntak, 2001)

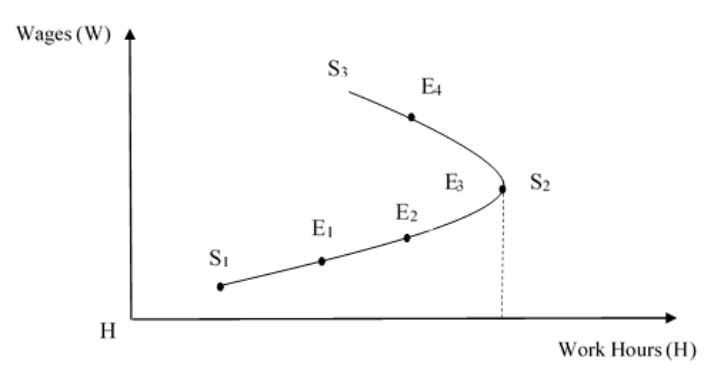

Figure 4. Supply of Labor Function Curve Source: (Simanjuntak, 2001)

Referring to Figure 4, up to the number of HD work hours, the time available to work increases due to the increase in wage level (S1S2). After reaching the amount of $\mathrm{HD}$ time, the family reduces the work hours if the wage level rises. A decrease in working hours due to an increase in the wage rate (S2S3) is called backward bending (Simanjuntak, 2001)

\section{The Definition of Labor}

Manpower is a resident who has worked and is working, looking for a job and doing other activities such as school and home care. The person can be said as a workforce except those who do not work activities (Simanjuntak, 2001).

According to law No. 13 of 2003 Article 1, labor is the person who can perform the work both in and outside the working relationship to produce goods and services to meet the needs of the community.

Labor or manpower consists of the labor force and not the labor force. The 
workforce or labor force is comprised of working groups and those who are idle and job-seeking. The non-working force group consists of the school, the class that takes care of the household, and another group of beneficiaries (Sumarsono, 2009).

\section{The industry is grouped into several parts}

According to Badan Pusat Statistik (2017) industry groupings based on manpower have been differentiated into four criteria: Large industry are industries that use the workforce of 100 people or more; Medium industry is an industry that uses labor between 20-99 people; Small industriy are industries that use manpower between 5-19 people; Industrial Micro/ household is an industry that uses labor less than five people.

Classifications of industry based on the asset value of net stipulated in law No. 9 of 1995: Large industry is business that owns net assets (without building and area) of 10 billion and above; Medium Industry is enterprises that have net assets (without building and area) between 200 million to 10 billion; small and micro industry is businesses with net assets (without building and area) not more than 200 million.

\section{Definition of Large and Medium Indus- try}

Law No. 9, the year 1995, on "Industry", mentions that the industry is an economic activity that processes raw materials, raw materials, semi-finished goods, and finished goods into products with a higher value for its use, including industrial design and engineering.

According to the Badan Pusat Statistik (2017) suggests that the processsing industry is an economic activity that conducts the activities of transforming an essential item mechanically, chemically, or by hand. So, it becomes finished, or semifinished goods and or goods that lack value into a higher-value thing, and its nature is closer to the end-user. Included in this activity are industrial services and assembly work.

A large industry that uses a workforce more than 100 people with significant capital that is collected collectively in the form of shareholding, energy must have unique skills and selection through the test of ability and feasibility. In contrast, the medium industry is an industry with a workforce of about 20 to 99 workers and with large capital.

Adding a new number of business units resulted in a company requiring a certain amount of manpower to carry out its business activities so that the absorbed workforce will also increase. This is reinforced by the results of research conducted by Anggriawan (2015) and Rachmatullail et al., (2016) that the variable number of industries has a positive influence on the variable amount of labor. Increased business units will influence the absorption of manpower in the region because, with the increasing number of business units, there will be a lot of new opportunities or new employment opportunities.

\section{Production value}

According to Latipah \& Inggit (2017) the value of production is the value of the whole goods and services, which is the result of the production process in a future business unit and sold to the hands of consumers. Based on Prastyaningsih (2016) and Hajrah (2017) research, The production value positively affects the absorption of energy, and the higher the production value in the industry, then indicates the increasing absorption of labor. It can happen because by increasing the production cost, the industry will need more labor.

\section{Private investments}

Investments are activities to allocate or invest current resources in the hopes of obtaining benefits later (Noor, 2009) The 
amount of investment value will determine the magnitude of the workforce used by the company. Theoretically, the higher the investment value done or instilled by a company, the higher the labor use (Suparmoko, 2000)

According to Noor (2009) Private investment is an investment made by the private to obtain benefits or profits. This type of investment is also known as investment term with a profit motive. Investments with characteristics like this can be made by private companies such as micro or household business, small and medium enterprises (SMES), and large companies such as BUMN or BUMD. Investing in the profit of this motive can be direct investment, such as establishing a variety of businesses (businesses) that produce goods and services to profit and indirect investments, such as creating a financial institution to raise funds to be channeled to the real sector. The benefit of this type of investment is to increase the value-added in the form of goods and services, employment, rent, interest, and business surplus. So it has a positive impact on economic development and the overall welfare of society.

The amount of private investment in an area in line with the resulting production value, the higher the number of private investments can result in increasing the cost of production, so the higher the labor is requested. According to Suharto \& Dharmala (2016) and Munandar (2016) research, there is a positive influence between private investments on the absorption of labor. If the private investment has increased, then the industry or company can be more developed, encouraging the birth of new industries and increasing the absorption of manpower to increase their productivity.

\section{Minimum wage}

Wages are an acceptance as a reward from an entrepreneur to a worker or employee for work or service that has been or is done, expressed or assessed in the form of money stipulated by an agreement or regulation, and is payable based on employment agreements between entrepreneurs and workers (Act No. 13 the year 2003).

In the regulation of the Minister of Manpower and Transmigration No. 7 of 2013, The minimum wage is a monthly lowest receipt consisting of a primary salary, including a fixed allowance set by the governor as a safety net. The minimum wage determination is based on the requirement of decent living (KHL) concerning productivity and economic growth.

Minimum wages are applied to improve community welfare and are expected to create jobs. The purpose of the minimum wage itself is as a safety net so that fees do not deteriorate, reducing the gap between the lowest and highest salary (equitable income), increased worker purchasing power and the expansion of employment opportunities, up to the increase of working productivity (Astari, 2018).

Based on the research of Wasilaputri (2016) and Astari (2018) shows that the minimum wage has a negative influence on labor absorption. When the minimum wage is set above the market wage, it causes the company to pay more workers. It can also be said that the company's production costs increase and will later affect the reduction in the amount of labor absorption.

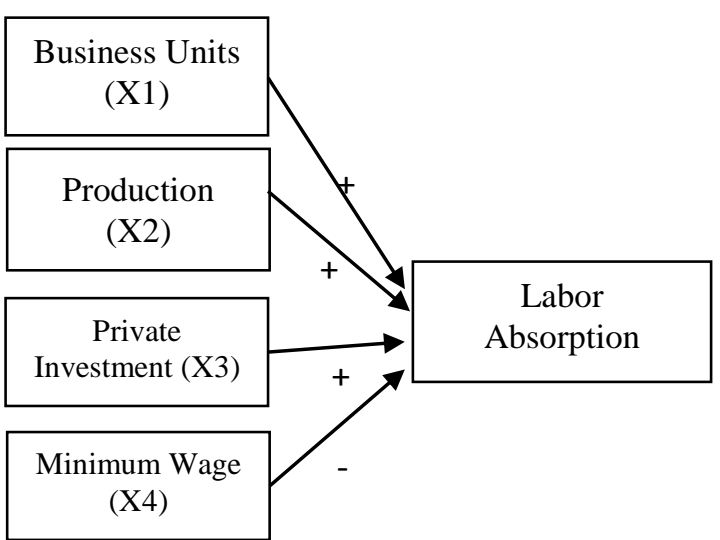

Figure 5. Conceptual Framework 


\section{RESEARCH METHODS}

The type of research conducted in this study is quantitative descriptive research. While the type of data used in this research is secondary data. The collection of secondary data from this research is a source from the Central Bureau of statistics, the Regional industrial office, the study of libraries, studying the theories of books by conducting appropriate analyses, and other sources that support the research. The population in this research is the whole large and medium industries six provinces in Java in 2008-2017.

The variables used in this study are categorized into two, i.e., dependent variables and independent variables.

The dependent variable in this study is the absorption of labor. Labor absorption is the number of workers working in large and medium industries DKI Jakarta, West Java, Banten, Central Java, East Java, and IN Yogyakarta IN the year 2008-2017. This variable uses the unit in the soul.

Independent variables in this study are business units, production value, private investment, and minimum wage of large and medium industries six provinces in Java in 2008-2017.

In this research, the analysis tools used are the analysis of the Classen typology and the Data regression analysis panel. Classical typological analysis is a combination of the average value of labor growth rate of labor absorption rate, while the analysis of the regression of data panels is a combination of data between place or space (cross-section) and data between time (time series).

\section{RESULT AND DISCUSSION}

According to the Badan Pusat Statistik (2017) Java Island is an island with the most significant amount of growth processing industry in Indonesia. The existing infrastructure is influencing the growth of the industrial processing of both small, medium, and large enterprises. Java island is administratively divided into six provinces, namely West Java, Central Java, East Java, Banten, and two special areas, namely DKI Jakarta and Yogyakarta.

\section{Typological Analysis of Klassen}

Klassen's Typology is an analytical tool that can be used to provide an overview of the patterns and structures of economic growth in each region (Mahdi et al., 2017) The absorption of large and medium industrial manpower mapping in six Java island Province. It can classify the category by specifying the average rate of labor growth large and medium industrial and average rate of labor absorption large and medium industrial by using the analysis of Klassen typology. (Shavira, 2017)

\begin{tabular}{|c|c|}
\hline Quadrant III & Quadrant I \\
$\bar{X}_{\mathrm{gi}}<\bar{X}_{\mathrm{g}}$ & $\bar{X}_{\mathrm{gi}}>\bar{X}_{\mathrm{g}}$ \\
$\bar{X}_{\mathrm{ti}}<\bar{X}_{\mathrm{t}}$ & $\bar{X}_{\mathrm{ti}}>\bar{X}_{\mathrm{t}}$ \\
\hline Quadrant IV & Quadrant II \\
$\bar{X}_{\mathrm{gi}}>\bar{X}_{\mathrm{g}}$ & $\bar{X}_{\mathrm{gi}}<\bar{X}_{\mathrm{g}}$ \\
$\bar{X}_{\mathrm{ti}}<\bar{X}_{\mathrm{t}}$ & $\bar{X}_{\mathrm{ti}}>\bar{X}_{\mathrm{t}}$ \\
\hline
\end{tabular}

Figure 6. Klassen Typology Classification

$\bar{X}_{\text {gi }}=$ average rate of labor growth large and medium industrial province

$\bar{X}_{\mathrm{g}}$ average rate of labor growth large and medium industrial Java Island

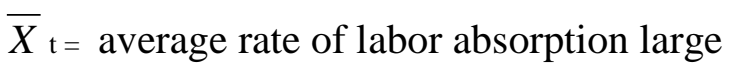
and medium industrial province

$\bar{X}_{\mathrm{t}=}$ average rate of labor absorption large and medium industrial Java Island

The results of the calculations showed the provincial position of DKI Jakarta, West Java, Banten, Central Java, East Java, and IN Yogyakarta into four quadrants of Classen in 2008-2017 were examined into four quadrants. 


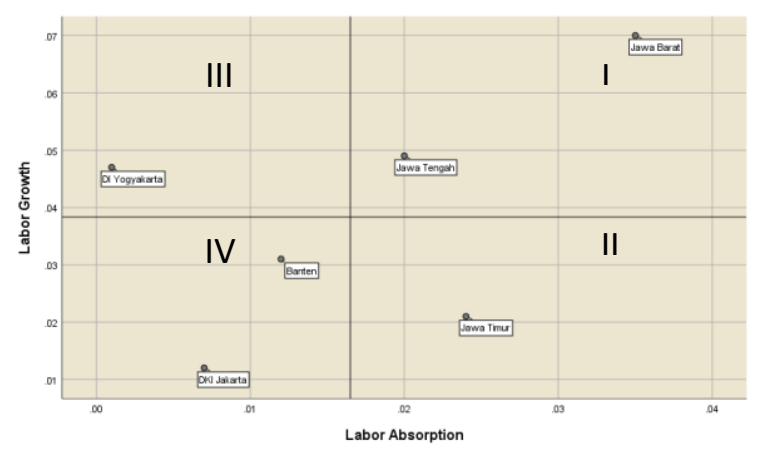

Figure 7. Klassen's Typology of Labor Absorption Rate and Growth Rate of Large and Medium Industry Workers on the Java Island

Source: SPSS Result

The classical typological analysis revealed that the area in the quadrants of I, namely West Java and Central Java province is the region with the classification of labor absorption of the big industry and fast-growing. It is demonstrated with the rate of absorption of large and moderate industrial human resources and the rate of growth of large and medium-high industrial labor in the region compared to other provinces in Java island. The level of large and medium absorption industries are advancing and overgrowing. It can be influenced by the high number of business units, production value, and private investment of large and medium enterprises and industrial sectors in West Java and Central Java is one of the flagship sectors that require a high amount of manpower.

The province which is in the area of Quadrant II is East Java province. The area is included in the classification of the labor absorption of large and medium industries that advanced but depressed. The region has a high level of industrial manpower absorption and moderate and the rate of growth of the large and moderate industrial workforce. It is influenced by the number of large and medium industry manpower, but the growth rate is stunted by the development of technology in large and medium industries. With the growing technology used, the industry can replace human labor with machine technology in the production process. Substituting such roles can result in a reduction in the amount of manpower used in the amount of energy absorption of large and medium industries in Java province.

The area of Quadrant III describes Yogyakarta's province with a relative classification left behind, which has a high level of industrial manpower absorption and low medium and the rate of growth of large and moderate industrial manpower. Low labor absorption is influenced by still enough the contribution of other sectors of the sector in the absorption of manpower in the Province of Yogyakarta, such as agriculture, forestry, and fisheries sectors.

DKI Jakarta and Banten provinces are included in the area of Quadrant IV with regional classification with the absorption of the large and moderate industrial manpower that is potential or can still thrive. DKI Jakarta and Banten provinces have the highest level of industrial manpower absorption and low growth rate and the high flow of industrial labor absorption. The low number of workers influences the absorption of labor in the area in the large and medium industrial sectors. However, the growing technology of making communities engaged outside the other sectors can move into a workforce in the industrial sector.

\section{Data Analysis Panel}

\section{Test Chow}

Based on the likelihood ratio results, it can be concluded that a more excellent model is a fixed-effect model. It is shown that the probability value Chi-square is $0.0000(<0.05)$, which indicates smaller than the significance value of $5 \%$, it makes the $\mathrm{H} 0$ is rejected, and $\mathrm{H} 1$ is accepted. (Gujarati, 2006). 


\section{Hausman Test}

Hausman test based on the results of the Hausmanini test, then it can be deduced that the most appropriate data for this panel is the Fixed Effect Model. It is shown that the probability value of ChiSquare is 0.0000 (< 0.05) meaning, H0 rejected, and H1 accepted (Gujarati, 2006).

\section{Normality Test}

The results of the test normality can be seen probability value of 0.074200 , stating that the probability value $>0.05$ and can be concluded that the data in this research is distributed normally. (Ghozali \& Ratmono, 2017).

\section{Multicholinerity Test}

The results of the multicollinearity test revealed that the correlation value between independent variables does not exceed 0.80 . it can be concluded that there was no problem with multicollinearity in this study. (Ghozali \& Ratmono, 2017).

Table 1. Fixed Effect Model Result

\begin{tabular}{ccccc}
\hline \multirow{2}{*}{ Variabel } & \multicolumn{5}{c}{ FEM } \\
\cline { 2 - 5 } & Coeffiecient & $\begin{array}{c}\text { Std. } \\
\text { Error }\end{array}$ & $\begin{array}{c}\text { t- } \\
\text { Statistic }\end{array}$ & Prob. \\
\hline C & 300057.1 & 73309.65 & 4.093010 & 0.0002 \\
\hline JU (X1) & 74.46085 & 22.86716 & 3.256235 & 0.0020 \\
\hline PRO (X2) & $1.97 \mathrm{E}-07$ & $1.25 \mathrm{E}-07$ & 1.569709 & 0.1228 \\
\hline INV (X3) & $2.92 \mathrm{E}-07$ & $3.89 \mathrm{E}-08$ & 7.497314 & 0.0000 \\
\hline UP (X4) & 0.005376 & 0.029156 & 0.184369 & 0.8545 \\
\hline $\begin{array}{c}\text { Adjusted R- } \\
\text { squared }\end{array}$ & \multicolumn{5}{c}{0.980399} \\
\hline F-Statistic & 328.9024 \\
\hline $\begin{array}{c}\text { Prob } \\
\text { (F Statistic) }\end{array}$ & 5 0.000000 \\
\hline
\end{tabular}

\section{Heteroskedastisity Test}

Based on the results of the Heteroskedasticity test in this study using the Whitedimana test, the results needed from this test are $\mathrm{Obs} * \mathrm{R}$-squared. The results showed that the $\mathrm{P}$-value $\mathrm{Obs} * \mathrm{R}$-squared value of 0.5246 was higher than $\alpha(\alpha=5 \%$ or 0.05$)$. It can be concluded that in this study, there were no problems with heteroskedasticity. (Ghozali \& Ratmono, 2017)

\section{Autoklinierity Test}

The DW test results have been done, the results of Durbin-Watson stat are obtained at 1.665419 , while the $\mathrm{dL}$ value in the table Sebsar 1.4443 and $\mathrm{dU}=$ 1.7274. Because the Count $\mathrm{D}$ value is more significant than $\mathrm{dL}$ and smaller $\mathrm{dU}$, it can be inferred does not occur positive autocorrelation. (Gujarati, 2006).

\section{Coefficient of determinant $\mathbf{R}^{2}$}

The results of the regression analysis reveal that the number of business Unit variables, production values, private investments, and Minimum wage jointly contributed to the influence of the large industrial labor absorption of 0.980399. It indicated that $98 \%$ of the variations variables are bound to be described by all free variables contained in the model. In comparison, the remaining $2 \%$ is described by other variables not inserted into the model. The adjusted value of R-Square shows that the research model is well used. (Ghozali \& Ratmono, 2017).

\section{Test $\mathbf{F}$}

In the Data estimation table, it can be seen that regression results influence the number of business units, the value of production, private investment, and Minimum wage against the absorption of large industrial manpower and is using a 95\% confidence level has a degree of freedom for the numerator (DFN) of $9(\mathrm{k}-1$ $=10-1)$ and a degree of freedom for the denominator (DFD) of $4(\mathrm{n}-\mathrm{k}=6-10)$, thus obtained F Table of 6.00 . Based on the results of such regression can be concluded that the f statistic > F-table (328.9024 > 6.00), then this means $\mathrm{H} 0$ rejected, and $\mathrm{H} 1$ accepted, which means that independent variables simultaneously affect the dependent variables significantly.

\section{Test $\mathbf{T}$}

The statistical analysis is partially used to see the significance of each free individually variable. In explaining the variables tied to the model using the T-test, 
the zero hypotheses $(\mathrm{H} 0: \beta=0)$ means the coefficient value equals zero. In contrast, the alternative hypothesis $(\mathrm{H} 1: \beta \neq 0)$ implies that the coefficient value is different from zero. This significance is directly viewable by the magnitude of the probability number. If the $\mathrm{P}$-value $(\mathrm{T}$ STAT) is smaller than $\alpha(\alpha=5 \%$ or 0.05$)$, then the free variable is significantly impactful to its own variables or reject $\mathrm{H} 0$. In addition to testing the signification $\mathrm{P}$ value (T-stat) with $\alpha$ by $5 \%$, the test also carried out on the efficiency value.

Based on the regression testing of this model, the variable number of business units and private investment have a significant influence on labor absorption. In contrast, production values variables and minimum wages do not have a considerable effect on influencing labor absorption.

The following models of equality estimation in this study are:

$$
\begin{array}{r}
\operatorname{Ln} Y_{i t}=300057,1+74,46085 \operatorname{Ln} x_{1}+1,97 E-07 \operatorname{Ln} x_{2} \\
+2,92 E-0,7 \operatorname{Ln} x_{3}+0,005376 \operatorname{Ln} x_{4}
\end{array}
$$
follows:

Overall it can be interpreted as

A constant value of 300057.1. It means that if the variable number of business units, production value, private investment, and Minimum wage is fixed or not experiencing addition or deduction (its value is zero), then the labor absorption amount to a constant value of 300057.1 .

The Coefficient value of total business Unit 74.46085. It shows that every Unit number increases one percent, then the labor absorption variable will rise by $74.46 \%$. It is assuming that the other free variables of the regression model are fixed. It is reinforced by the results of research conducted by Anggriawan (2015) and Rachmatullail et al., (2016) that the variable number of industries has a positive influence on the variable amount of labor. The increase in the number of business units resulted in a company requiring an amount of manpower to carry out its business activities so that the absorbed workforce will also increase.

The coefficient value of production value of $1.97 \mathrm{E}-07$. It implies that the increase in the production value of one percent, hence the absorption variable of labor, will increase by $1.97 \mathrm{E}-07 \%$. It is assuming that the other free variables of the regression model are fixed. Based on the research of Prastyaningsih (2016) and Hajrah (2017), Production values positively affect the absorption of energy, the higher the cost of production in the industry then indicates the increasing absorption of labor. It can happen because by increasing the value of production. Then the industry will need more labor.

The value of the private investment coefficient $2.92 \mathrm{E}-07$. It implies that every individual investment increase by one percent; the labor absorption variable will rise by $2.92 \mathrm{E}-07 \%$. It is assuming that the other free variables of the regression model are fixed. It is in according to the research of Suharto \& Dharmala (2016) and Munandar (2016), there is a positive influence between private investments on the absorption of labor. If the private investment has increased, then the industry or company can be more developed, encouraging the birth of new industries and increasing the absorption of manpower to increase their productivity.

Minimum wage coefficient of 0.005376. It means that each Minimum wage is a one percent increase, then the labor absorption variable will rise by $0.005376 \%$. It is assuming that the other free variables of the regression model are fixed. This result means that the minimum wage has a positive influence on the absorption of human resources. It is not by the hypotheses based on the research of Wasilaputri (2016) and Astari (2018), indicating that the minimum wage has a negative influence on labor absorption. Fees are the primary goal of a Labor offer. 
The higher the salaries imposed on labor, the higher the offer will be. Like the nature of each individual in meeting the needs, the work Seorangtenaga also always strive to maximize its satisfaction, namely strive to seek high wages so that the level of labor absorption is also increased.

Based on the study results, it is known that the number of business units is the most significant factor, which is 74.46085 compared to the production value, private investment, and Minimum wage against the absorption of large industrial manpower is in 6 Java island provinces.

\section{CONCLUSION AND RECOMMEN- DATION}

Conclusion of this research is results of analysis using Typology Klassen can be known as the area in the quadrant I with the classification of the advanced labor absorption and overgrowing in the province of West Java and Central Java. The area that is in the quadrant II with the classification of the advanced labor and depressed and the area that resides in Quadrant IV with the classification of potential labor absorption or still can develop is DKI Jakarta and Banten; Analysis of data panel shows that partial number of business units and private investment have a positive influence and significant to the absorption of labor of large and medium Enterprises 6 provinces in Java Island, while production value and minimum wage have a positive and insignificant impact on the absorption of power of large and medium Industries 6 provinces in Java Island; the factors that have the most significant influence on the absorption of large industrial human resources and are in 6 Island Java province is the number of business units. If the number of industries is getting higher, then the absorbent workforce is also getting bigger; and Based on simultaneous testing or jointly, the number of business units, production value, private investment, and the minimum wage has a significant influence on the absorption of manpower in the massive industry six provinces in Java Island.

Recommendations of this research is The provincial government is expected to create appropriate regional regulations by maintaining the quality of transportation infrastructure, both land and sea. So, the distribution of goods and services is not experiencing problems. Therefore, it will facilitate and increase the public or private wishes to establish new industrial business units; Local governments are expected to increase and develop large industrial sectors. They are 6 provinces in Java Island by facilitating the granting of permits to investors in investing. Governments need to invest in the public for the development of large and medium industrial sectors. So that increased production of goods and services will increase and labor also increased; Large and medium industries are expected to continue to maintain or even increase production value to increase the absorption of labor 6 provinces in Java Island; and The industry sector is expected to determine the wage policy for workers, with a decent wage rate given to the workers; it will motivate the workers to be able to increase their productivity.

\section{LIMITATION}

The most recent time period is due to the limited availability of data on several variables used in this research.

\section{REFERENCES}

Anggriawan, R. (2015). Analisis Penyerapan Tenaga Kerja Pada Sektor Industri Manufaktur (Besar Dan Sedang) di Provinsi Jawa Timur Tahun 2007-2011. Jurnal Ilmiah, 24. https://doi.org/10.33005/jedi.v3i01.39

Astari, A. iIdah. (2018). Pengaruh kebijakan upah minimum terhadap penyerapan tenaga kerja industri besar - sedang di indonesia tahun 2011 - 2016. Institut Pertanian Bogor. 
Badan Pusat Statistik. (2017). Statistik Industri Manufaktur. Badan Pusat Statistik.

Feriyanto, N. (2014). Ekonomi Sumber Daya Manusia; dalam Perspektif Indonesia. UPP STIM YKPN.

Ghozali, I., \& Ratmono, D. (2017). Analsiis Multivariat dan Ekonometrika (2nd ed.). Badan Penerbit Universitas Diponegoro.

Gujarati, D. N. (2006). Dasar-dasar Ekonometrika (Ketiga). Erlangga.

Hajrah. (2017). Pengaruh Nilai Produksi, Investasi, dan Jumlah Unit Usaha terhadap Penyerapan Tenaga Kerja pada Sektor Industri Kecil dan Menengah di Kota Makassar [Universitas Islam Negeri Alauddin Makassar].

https://doi.org/10.1017/CBO9781107 415324.004

Karib, A. (2012). Analisis Pengaruh Produksi, Investasi dan Unit Usaha terhadap Penyerapan tenaga Kerja pada Sektor Industri Sumatera Barat. Jurnal Manajemen Dan Kewirausahaan, 3(3), 61.

Latipah, N., \& Inggit, K. (2017). Analisis Penyerapan Tenaga Kerja Pada Sektor Industri Besar Di Provinsi Jawa Timur Tahun 2009-2015. Jurnal Ekonomi \& Bisnis, 2, 479-492. https://doi.org/10.1360/N97201600877

Mahdi, Amril, \& Syaifuddin. (2017). Pertumbuhan dan Tipologi Pertumbuhan Sektor Pertanian Kabupaten Tanjung Jabung Barat. E-Jurnal Perspektif Ekonomi Dan Pembangunan Daerah, 6(2), 65-76.

Mankiw, N. G. (2011). Pengantar Ekonomi Mikro (Ketiga). Salemba Empat.

Munandar, A. (2016). Pengaruh Investasi Swaasta Terhadap Penyerapan Tenaga Kerja Di Provinsi Aceh. Universitas Teuku Umar.

Noor, H. F. (2009). Invetasi Pengelolaan Keuangan Bisnis dan Pengembangan Ekonomi Masyarakat. Indeks.
Prastyaningsih, A. (2016). Analisis Penyerapan Tenaga Kerja Pada Sektor Industri Besar dan Sedang SeEks Karesidenan Surakarta Tahun 2006-2013. Universitas Muhammadiyah Surakarta.

Rachmatullail, C., Fathorrazi, M., \& Santosa, S. H. (2016). Faktor- faktor yang Mempengaruhi Penyerapan Tenaga Kerja Pada Sektor Industri Pengolahan di Kota Surabaya. Artikel Ilmiah Mahasiswa.

Shavira, D. Y. (2017). Faktor-Faktor yang Mempengaruhi Penyerapan Tenaga Kerja di Indonesia Tahun 2011-2015. Institut Pertanian Bogor.

Simanjuntak, P. J. (2001). Pengantar Ekonomi Sumber Daya Manusia. Lembaga Penerbit Fakultas Ekonomi Universitas Indonesia.

Suharto, U. S., \& Dharmala, R. (2016). Investasi Swasta, Upah Minimum Regional Dan Pertumbuhan Industri Besar Dan Sedang Terhadap Penyerapan Tenaga Kerja Di Provinsi Banten. Jurnal Ekonomi-Qu, 6(1), 81-99.

https://doi.org/10.35448/jequ.v6i1.41 98

Sukirno, S. (2012). Teori Pengantar Makro Ekonomi (Edisi Keti). PT RajaGrafindo Persada.

Sumarsono, S. (2009). Teori dan Kebijakan Publik: Ekonomi Sumber Daya Manusia. Graha Ilmu.

Suparmoko. (2000). Pengantar Ekonomi Makro. BPFE Universitas Gadjah Mada.

Wasilaputri, F. R. (2016). Pengaruh Upah Minimum Provinsi, PDRB Dan Investasi Terhadap Penyerapan Tenaga Kerja Di Pulau Jawa Tahun 2010-2014. Universitas Negeri Yogyakarta. 